\title{
Archaeological prospections in the Roman vicus Belginum (Rhineland-Palatinate, Germany)
}

\author{
Wolf-Rüdiger Teegen ${ }^{1,2}$, Rosemarie Cordie ${ }^{3,4}$, Philomena Over ${ }^{1}$, Simon Mägdefessel $^{1}$, Rebecca Retzlaff ${ }^{5}$, and \\ Johannes Stoffels ${ }^{5}$ \\ ${ }^{1}$ Institut für Vor- und Frühgeschichtliche Archäologie und Provinzialrömische Archäologie, \\ Ludwig-Maximilians-Universität, Munich, 80539, Germany \\ ${ }^{2}$ ArchaeoBioCenter, Ludwig-Maximilians-Universität, Munich, 80539, Germany \\ ${ }^{3}$ Klassische Archäologie, Universität Trier, Trier, 54286, Germany \\ ${ }^{4}$ Archäologiepark Belginum, Morbach-Wederath, 54497, Germany \\ ${ }^{5}$ Umweltfernerkundung und Geoinformatik, Universität Trier, Trier, 54286, Germany
}

Correspondence: Wolf-Rüdiger Teegen (w.teegen@lmu.de)

Relevant dates: $\quad$ Received: 31 January 2019 - Accepted: 21 March 2019 - Published: 11 April 2019

How to cite:

Teegen, W.-R., Cordie, R., Over, P., Mägdefessel, S., Retzlaff, R., and Stoffels, J.: Archaeological prospections in the Roman vicus Belginum (Rhineland-Palatinate, Germany), E\&G Quaternary Sci. J., 68, 5-11, https://doi.org/10.5194/egqsj-68-5-2019, 2019.

Abstract:

The Roman vicus Belginum and the associated Celtic-Roman cemetery have been the subject of systematic archaeological research since 1954. Since 2004, archaeological prospections have been carried out in and around Belginum. Participants included students from the universities of Leipzig, Trier, and Munich as part of study-accompanying field work.

This paper deals with the prospections of 2004 and 2016, when nearly 2 ha of land south of the federal road B327 (Hunsrückhöhenstraße) were surveyed. The study area is located on a NW-to-SErunning hillside. All non-local objects present on the surface were collected and three-dimensionally recorded. Previously in 2013, the area was geomagnetically prospected by Posselt \& Zickgraf (Marburg). Both surveys revealed a hitherto unknown extent of the vicus about $200 \mathrm{~m}$ to the southwest. The findings date back to the late first to third centuries common era.

All finds (ceramic, bricks, roof slate, glass, and metal) were recorded and analysed in a QGIS and ArcGIS environment together with lidar scans, the geomagnetic data, and other geographical information. The overall distributions of bricks and pottery were studied in detail. The distribution of bricks is in particular connected to the individual plots, while the pottery is mainly concentrated in the backyards. Regarding surveys in other Roman vici, the brick distribution could be a helpful indicator to identify plots, when no geophysical information is available.

Kurzfassung: $\quad$ Der römische vicus Belginum und das zugehörige keltisch-römische Gräberfeld sind seit 1954 Gegenstand systematischer archäologischer Forschungen. Seit 2004 werden archäologische Prospektionen in und um Belginum durchgeführt. Beteiligt waren Studierende der Universitäten Leipzig, Trier und München im Rahmen von Lehrveranstaltungen.

Diese Veröffentlichung stellt die Ergebnisse der Prospektionen von 2004 und 2016 vor. Prospektiert wurden etwa 2 ha Fläche südlich der Hunsrückhöhenstraße B327. Das begangene Areal liegt auf 
einem von NW zu SO verlaufenden Hang. Sämtliche auf der Geländeoberfläche beobachteten nichtlokalen Gegenstände wurden dreidimensional eingemessen und eingesammelt. Bereits 2013 war das Gebiet von der Firma Posselt \& Zickgraf (Marburg) geomagnetisch prospektiert worden. Beide Surveys ergaben eine bis dahin unbekannte Ausdehnung des Vicus um $200 \mathrm{~m}$ nach Westen. Die datierbaren Funde, überwiegend Keramik, gehören in den Zeitraum zwischen dem späten 1. Jh. und dem 3. Jh. n. Chr.

Sämtliche Funde (Keramik, Ziegel, Dachschiefer, Glas und Metall) wurden in einer Lehrveranstaltung aufgenommen. Die Daten wurden in einer QGIS- und ArcGIS-Umgebung zusammen mit Lidar-Scans, den geomagnetischen Daten und anderen geographischen Informationen analysiert. Die Gesamtverteilungen der Ziegel und Keramik wurden detailliert untersucht. Vor allem die Verteilung der Ziegelfunde folgt den einzelnen, auf dem Magnetometerplot erkennbaren Parzellen. Die Keramik ist dagegen überwiegend im Hinterhofbereich konzentriert. Bei zukünftigen Prospektionen in anderen römischen vici kann die Verteilung der Ziegelfunde ein wichtiges Hilfsmittel zur Identifizierung von Grundstücksparzellen darstellen, wenn keine geophysikalischen Daten vorliegen.

\section{Introduction}

Wederath-Belginum (Gde. Morbach, Kr. BernkastelWittlich; localization: Fig. 1, insert) is one of the remarkable rural archaeological sites in Rhineland-Palatinate, Germany. The archaeological ensemble consists of a Celtic and Roman cemetery, the Roman vicus Belginum with at least three sanctuaries and an early Roman military camp (Fig. 1). The ancient name of the vicus is known from a Roman inscription (... vicani belginates...) and from the well-known Tabula Peutingeriana (Haffner, 1989, inside back cover).

Belginum was located at the intersection of the ancient west-east road, linking the capitals of the Roman provinces Gallia Belgica and Germania Superior, TrierAugusta Treverorum and Mainz-Mogontiacum, and the north-south route connecting the rivers Moselle and Nahe (Haffner, 1989).

The site Wederath-Belginum has been the subject of systematic archaeological research since 1954 (overview in Haffner, 1989, and Cordie, 2007). The burial ground has been comprehensively published in six volumes so far (details and references in Cordie, 2007).

Excavations in the settlement area itself were carried out in 1969-1973 and 2000-2014. The excavations showed that strip houses were present at the Belginum. They are typical for the Roman northwest provinces. The plots are about $10 \mathrm{~m}$ wide and up to $80 \mathrm{~m}$ long. A (stone) cellar is located near to the street and the building begins above the cellar. A porticus is set in front of the house. The house with half-timbered construction extends about 20-25 m into the rear part of the property (Cordie et al., 2013). Such a plot organization can also be seen on the images of the new geomagnetic prospections (see Figs. 2-3).

\section{Material and methods}

\subsection{Prospection and data}

Since 2004, prospections of various types have been carried out at the Belginum site in the framework of course-related university training with the aim to gain knowledge of the Iron Age settlement (Lukas et al., 2012), the Roman land use, and the extent of the vicus. Students participating came from the universities of Leipzig (UL), Trier (UT), and Munich (LMU). Within Belginum's surroundings (Fig. 1), several villae rusticae and at least one settlement of pre-Roman Iron Age could be identified as reported by Teegen et al. (2014, with further references).

\subsubsection{Prospection 2004}

Already in late autumn of 2004, an approximately $50 \mathrm{~m}$ wide and $200 \mathrm{~m}$ long strip of ground had been prospected by UL students and staff, along the road to Hintzerath (EV2004,167) (Fig. 1 No. 1). A large number of finds were discovered in 1670 spots. The Roman pottery and the glass finds generally date back to the first to third centuries common era. The find distributions were analysed in a LMU bachelor thesis by Mägdefessel (2018) using the geographic information system QGIS (QGIS Development Team, 2018).

\subsubsection{Geomagnetic prospection 2013}

In advance of the construction work for the federal road B50neu, large areas south of the federal road B327 (Hunsrückhöhenstraße) were geomagnetically prospected in 2013 by the company Posselt \& Zickgraf (Marburg) (see below Figs. 2-3). Surprisingly, it turned out that the vicus extends about $200 \mathrm{~m}$ further to the west. 


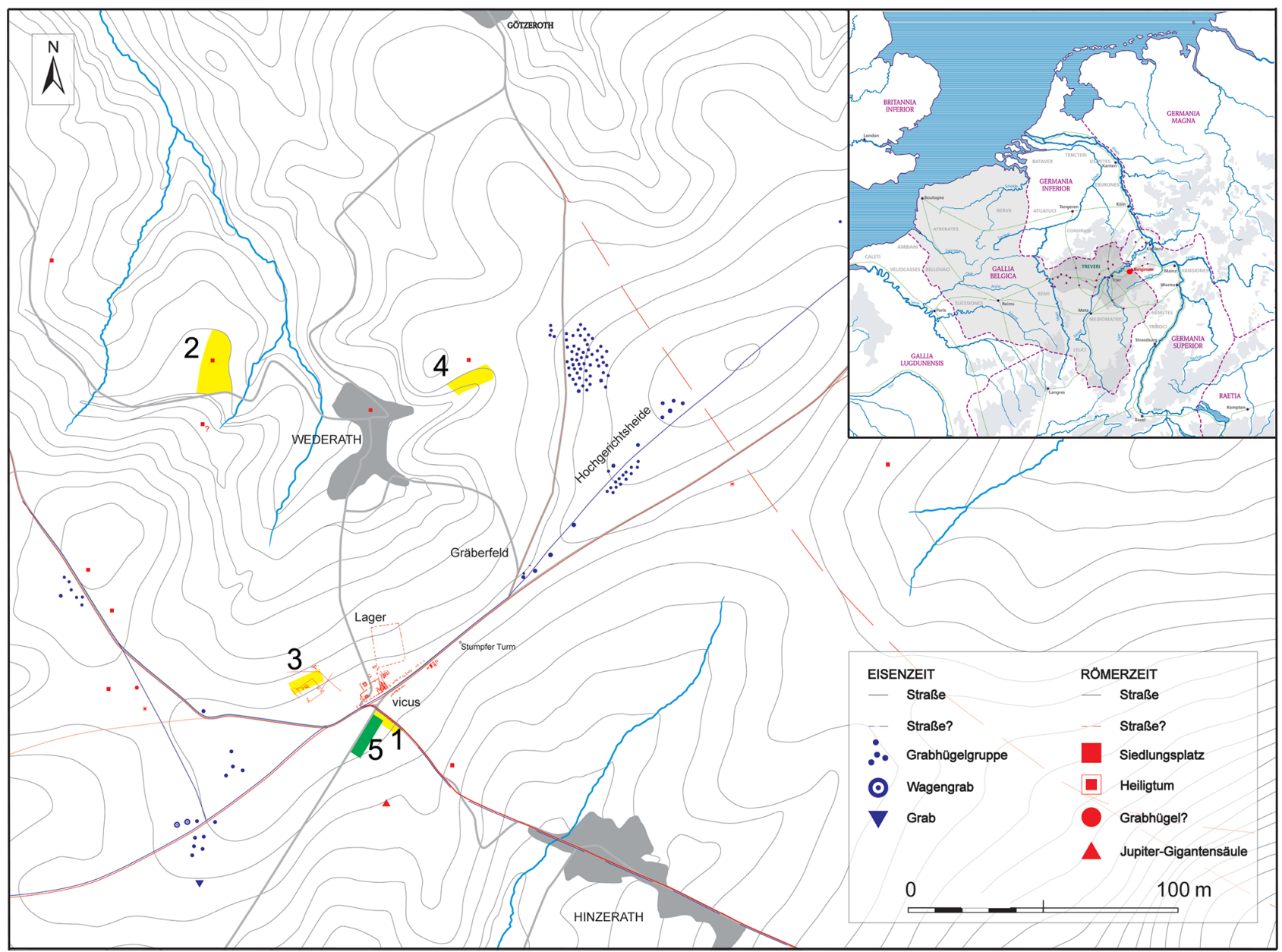

Figure 1. The archaeological site Wederath-Belginum during the Iron Age (Eisenzeit) and the Roman times (Römerzeit). Localization of archaeological features, and the survey areas from 2004 to 2008 (1-4, yellow) and 2016 (5, green). Archaeological features are as follows. Vicus: Roman vicus; Lager: Roman military camp; Gräberfeld: Celtic and Roman cemetery; "StumpferTurm": medieval tower. Legend is as follows. Straße: road; Grabhügelgruppe: group of tumuli; Wagengrab: wagon burial; Grab: burial; Siedlungsstelle: villa rustica; Heiligtum: sanctuary; Jupiter-Gigantensäule: column of Jupiter and the Giants (map: Marco Schrickel, Jan König, Wolf-Rüdiger Teegen). The insert shows a localization of the site Belginum (red) in the Roman province Gallia Belgica (map: Archaeological Park Belginum).

\subsubsection{Prospection 2016}

In October 2016, a joint field exercise for 10-15 students of (geo-)archaeology and geo-informatics organized by UT and LMU was carried out in the vicinity of Belginum in an agricultural field of approximately 1 ha in size located at the southern side of the federal road B327 within the parish Hundheim (Fig. 1 No. 5) (EV2016,205).

During the first couple of days, the students surveyed the field on a $1 \mathrm{~m}$ density grid. All non-local finds (pottery, bricks, glass, metal, etc.) were deposited into plastic bags together with a unique identification code. These were then three-dimensionally sited by means of a total station (Leica) and a differential Global Navigation Satellite System (GNSS) (TopconPositioning Systems, Inc.). As collected fragments in 2016 were abundant, the finds of the site's western part were sampled at $5 \mathrm{~m} \times 5 \mathrm{~m}$ quadrants. All to- gether 2856 find locations were sampled containing a total of 9979 finds.

The aim of this prospection was to gather information about dating and material culture in this newly discovered western part of the settlement.

\subsection{Data integration and analysis in GIS}

The archaeological finds were inventoried and classified into the general material groups pottery, bricks, roof slate, glass, and metal during another course at LMU. They were later recorded in an Excel spread sheet. In the consecutive GIS exercise in 2017, these tables were integrated into an ArcGIS geodatabase, which required reorganization of the standard archaeological table structure into an appropriate geodata format. The prospection areas of 2004 and 2016 partly overlap at the north-northeastern region south of the federal 

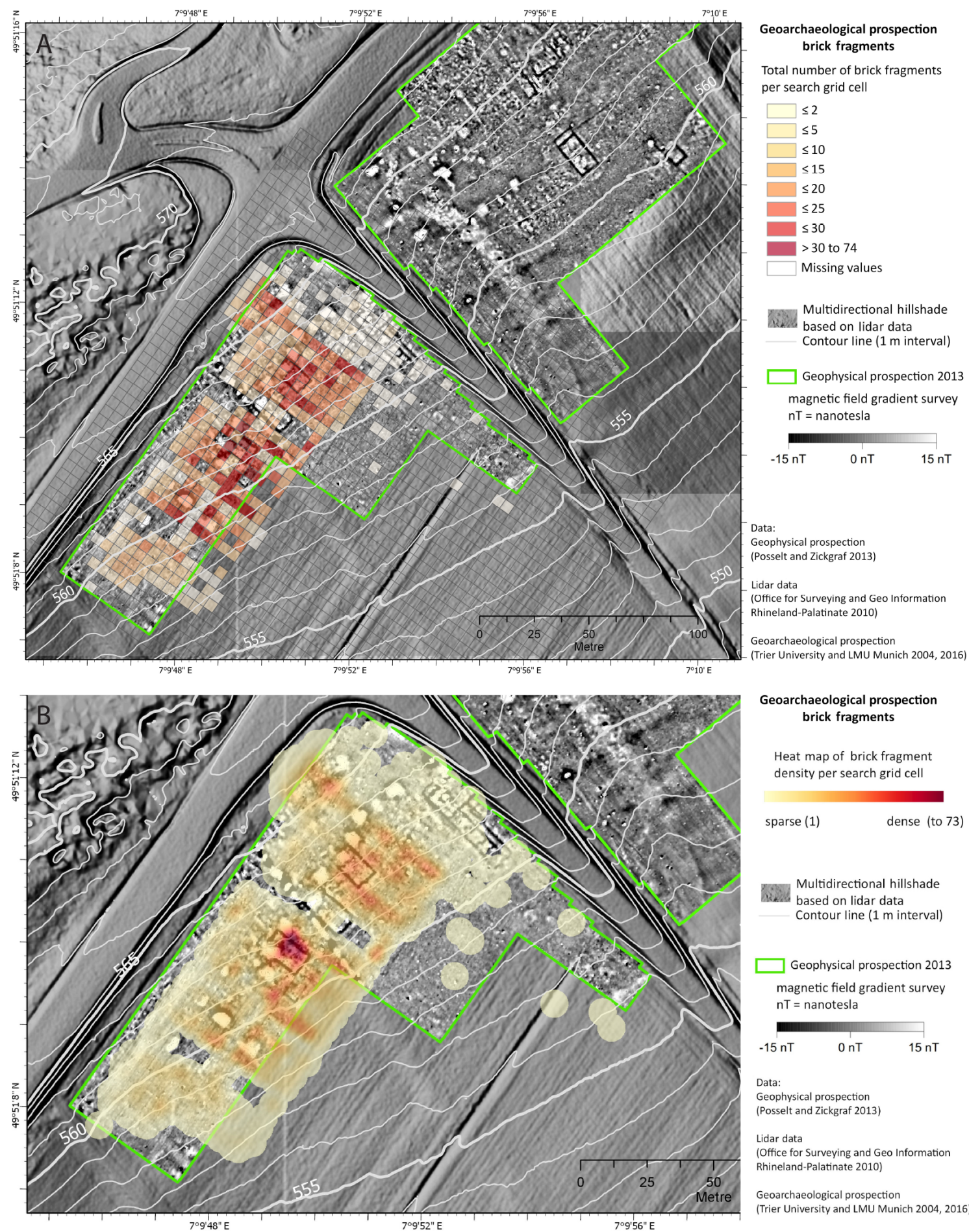

Geoarchaeological prospection brick fragments

Heat map of brick fragment density per search grid cell

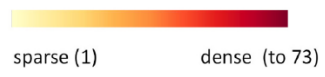

\section{Multidirectional hillshade based on lidar data Contour line (1 $\mathrm{m}$ interval)}

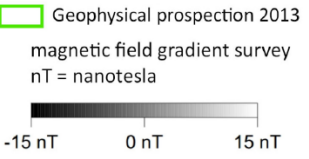

Data:

Geophysical prospection (Posselt and Zickgraf 2013)

Lidar data

(Office for Surveying and Geo Information Rhineland-Palatinate 2010)

Geoarchaeological prospection (Trier University and LMU Munich 2004, 2016)

Figure 2. Wederath-Belginum, archaeological survey 2004, 2016. (a) Total number of brick fragments (1 to 74) per search grid cell (5 $\mathrm{m} \times$ $5 \mathrm{~m}$ ) in the western part of the vicus (GIS map: Johannes Stoffels). (b) Close-up of the heat map of brick fragments (1 to 74) per search grid cell $(5 \mathrm{~m} \times 5 \mathrm{~m})$ in the western part of the vicus (GIS map: Johannes Stoffels). 

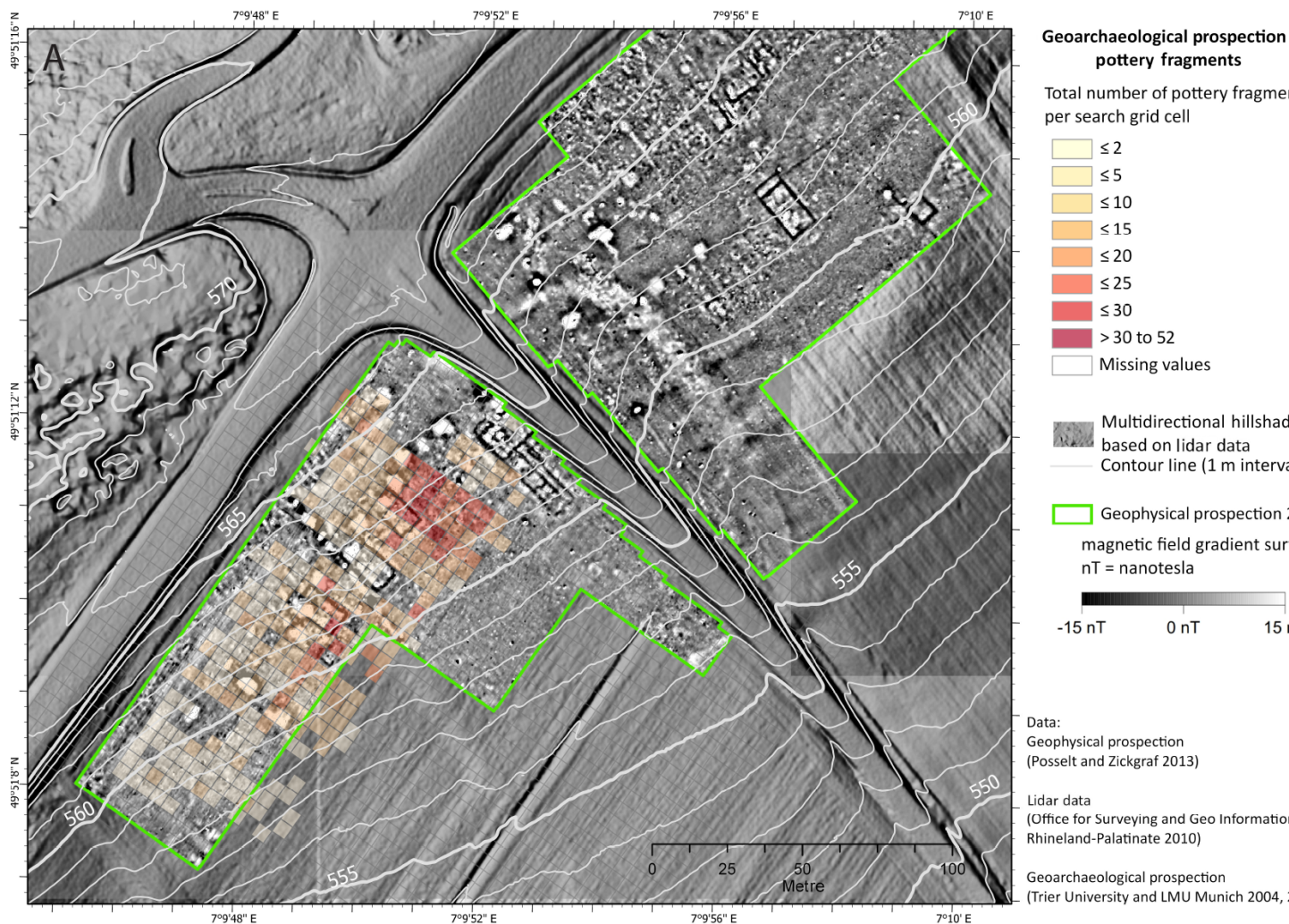

Total number of pottery fragments per search grid cell
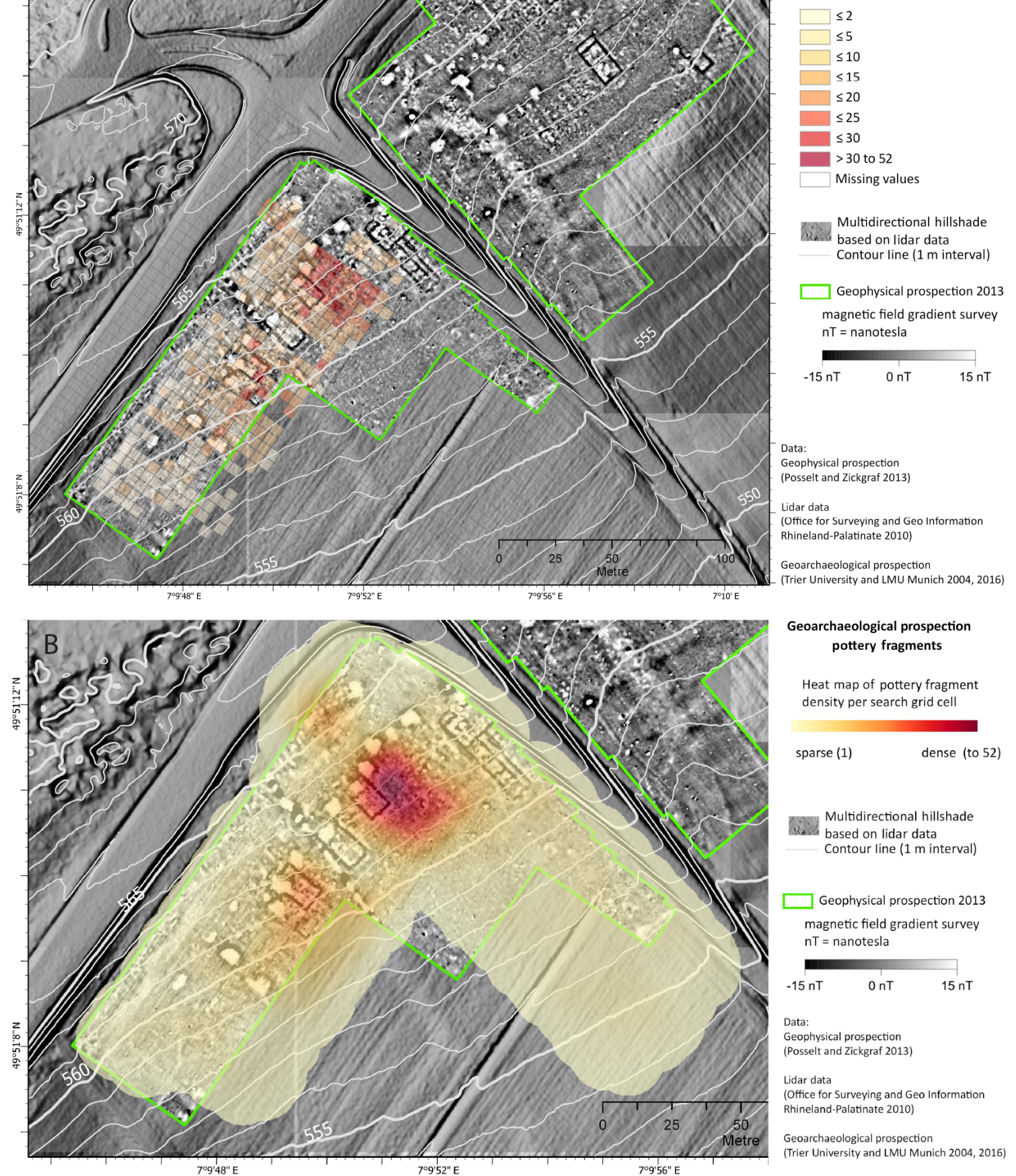

Figure 3. Wederath-Belginum, archaeological survey 2004, 2016. (a) Total number of pottery fragments (1 to 52) per search grid cell $(5 \mathrm{~m} \times 5 \mathrm{~m})$ in the western part of the vicus (GIS map: Johannes Stoffels). (b) Close-up of the heat map of pottery fragments (1 to 52) per search grid cell $(5 \mathrm{~m} \times 5 \mathrm{~m})$ in the western part of the vicus (GIS map: Johannes Stoffels). 
road Hunsrückhöhenstraße B327 (see Fig. 1 No. 1 and 5). The 3-D position data were projected to ETRS89/UTM32N and archaeological attribute data were merged with the point data for further find density analysis following Allen (2016), exemplary for pottery and bricks. In concordance to the sampling, a regular fishnet of $5 \mathrm{~m}$ cells was generated and oriented to follow the study site orientation (SW-NE) as a base for density mapping by summarizing finds for each respective cell (Figs. 2a-3a). Finds were further described by kernel density maps (heat maps) visualizing the number of bricks or pottery fragments for a search grid cell of $5 \mathrm{~m} \times 5 \mathrm{~m}$ (Figs. 2b-3b) (Silverman, 1986). Furthermore, the geomagnetic prospection, Rhineland-Palatinate's lidar scans, and topographic raster maps were available. From the lidar elevation data, a multidirectional hillshade raster and contour lines were derived at $5 \mathrm{~m}$ elevation intervals. The aim was (a) to explore the data and (b) to map and analyse the occurrence of material groups, which were also further analysed in a bachelor thesis at LMU (Over, 2018) using QGIS.

\section{Results and interpretation}

The classification and inventory of the finds during a course in winter 2016/17 at LMU revealed a dating in a time span from the late first to the third centuries common era. This is consistent with the results of the 2004 prospection (see above). During another course in winter 2018/19 at LMU, handmade pottery of the late Latène or early Roman period (second half of the first century before common era) was discovered. This is the first indication for a late Latène (late preRoman) to early Roman settlement at Belginum itself.

The data collected in the above-mentioned bachelor theses (Over, 2018; Mägdefessel, 2018) were summarized in the overall mapping using ArcGIS (see Figs. 2-3).

The geomagnetic prospection from 2013 (Posselt \& Zickgraf) revealed several cellars and some houses south of the B327 (see Figs. 2-3). The width of the houses is mostly equal to the plot widths. There is, however, sometimes a small distance between the houses, as the excavations in the last decades have shown (Cordie, 2007). Every house has a quadrangular or rectangular cellar in its front part. The width of the cellars is sometimes equal to the house or plot widths. In general, the cellars are smaller.

The number of fragments per search grid cell and the kernel density map of the bricks (Figs. 2-3) show a clear relation to the single plots. The bricks are distributed from the cellars to the probable house extents up to the backyard area. This means a distance of 30 to $40 \mathrm{~m}$. The finds concentrate in the longitudinal axis of the plots. There is a decreasing intensity of finds to the lateral periphery of the plots. The same distribution may be observed for the adjacent plots. We can, therefore, assume that the distribution of bricks mirrors the houses on the single plots. This is quite an important result for further archaeological prospections on Roman sites, where no geophysical information is available. Here, a reconstruction of the plots would be possible, using the density distributions of bricks.

Focussing on the density or heat maps of bricks within the houses (see Fig. 2), we can see a strong concentration of bricks within the houses. This is probably due to the fact that after leaving the houses at some point the roof truss collapsed inwards (see Bentz, 2013, p. 78). As a result, the roof tiles fell into the interior of the house. This is a quite different mechanism compared to earthquakes, where walls generally collapse to the outside (Stiros, 1995, p. 729, Fig. 4).

From the excavations of the years 1969-1973 and 20002014 in the vicus Belginum, we know that the place was not subject to a fire disaster, but had been abandoned. The descriptions of the ruins of the vicus in the early 19th century show that at that time some of the houses towered right up to the first floor (Merten in Cordie, 2007). In the middle and second half of the 19th century, stone and bricks were robbed for modern road and house construction and thus completed the destruction of the vicus. Today, not a single upright wall is present. However, part of the vicus must have already been demolished in late antiquity. The new burgus, discovered during rescue excavations in 2015 , clearly shows the walls were constructed with secondary building materials.

The distribution of the ceramic sherds shows a different pattern (Fig. 3). Here, the finds are concentrated in the rear part of some houses and in the backyard area. The major concentration of pottery is present in the rear part and in the backyard of three houses in the northern part of the survey area (Fig. 3). From an archaeological perspective, this distribution makes sense. When a Roman strip house is excavated, the major quantity of (storing) vessels, glass, and other household items will be discovered in the backyard. Here, the waste pits are usually localized. The waste pits were partly destroyed due to agricultural work in the last 2 centuries, and their contents came to light. The plowing activity might shift ceramics and other finds downhill by about $\geq 5 \mathrm{~m}$.

\section{Prospect}

This work has shown that curricular practical course prospections bring further insights into settlement archeology. This can be achieved with systematic field surveys, geophysical surveys, lidar scans, and aerial photographs obtained by plane, drone, or fixed-wing unmanned aerial vehicle.

The use of various archaeological and geophysical prospection methods and the following GIS analyses brought a significant gain in knowledge for the site Belginum regarding size and type of development - without excavation.

Data availability. For the next years, there is an ongoing project regarding the spatial distribution of pre-Roman and Roman findings in the vicus Belginum. This will result in some theses at LMU and UT. Furthermore, due to illegal activities of non-authorized detec- 
torists, find co-ordinates will not be published. They will be, however, stored in due course in the find archive of the Rheinisches Landesmuseum Trier.

Author contributions. RC and WRT organized the archaeological prospection, funding, and the identification of the findings. RR and WRT were responsible for on-site data catchment. JS and RR organized the GIS course and GIS analysis. JS, RR, SM, and PO analysed GIS data. WRT and RC interpreted GIS data. WRT and $\mathrm{RR}$ wrote the paper with contributions from all co-authors.

Competing interests. The authors declare that they have no conflict of interest.

Special issue statement. This article is part of the special issues "Geoarchaeology and past human-environment interactions". It is not associated with a conference.

Acknowledgements. The work has been carried out using ESRI ArcGIS and QGIS. Special thanks go to the students eagerly collecting fragments despite sometimes harsh weather conditions. Lidar and topographic map raster data (Basis-DLM) have kindly been provided by Rhineland-Palatinate's surveying office Vermessungsund Katasterverwaltung (topicality), 2014, 2015. The Archaeological Heritage of Rhineland-Palatinate at Trier (GDKE) kindly gave the necessary permissions. The group of students from Munich was gratefully supported by LMU and the local archaeological association (Förderverein Archäologiepark Belginum e.V.). For correcting the English in a previous version of the paper, we are grateful to Anneli O'Neill (LMU Munich). All remaining errors are, of course, our own.

\section{References}

Allen, D. W.: GIS Tutorial 2: Spatial Analysis Workbook (GIS Tutorials), 4th edn., ESRI Press, Redlands, USA, 2016.

Bentz, M.: Das Handwerkerviertel von Selinunt. Die Töpferwerkstatt in der Insula S 16/17-E, Vorbericht zu den Kampagnen 2010-2012, Röm. Mitteil., 119, 69-98, 2013.
Cordie, R. (Ed.): 50 Jahre Ausgrabungen und Forschungen, Schriften des Archäologieparks Belginum 5, Philipp von Zabern, Mainz, Germany, 2007.

Cordie, R., König, J., and Teegen, W.-R.: Der vicus von Belginum. Zum Stand seiner Erforschung, in: Neue Forschungen zu zivilen Kleinsiedlungen (vici) in den römischen Nordwest-Provinzen, edited by: Heising, A., Akten der Tagung Lahr, 21-23 October 2010, Verlag Dr. Rudolf Habelt, Bonn, Germany, 101-118, 2013.

Haffner, A. (Ed.): Gräber - Spiegel des Lebens, Schriftenreihe des Rheinischen Landesmuseums Trier 1, Philipp von Zabern, Mainz, Germany, 1989.

Lukas, D., Teegen, W.-R., Cordie, R., Schrickel, M., König, J., and Fleischer, F.: Auf der Suche nach den Kelten - Systematische Prospektionen im Umkreis von Belginum, in: Die Eisenzeit zwischen Champagne und Rheintal, edited by: Schönfelder, M. and Sievers, S., 34. Internationales Kolloquium der Association Française pourl'Étude de l'âge du Fer, 13-16 May 2010, Aschaffenburg, Römisch-Germanisches Zentralmuseum, Mainz, 263-290, 2012.

Mägdefessel, S.: Eine GIS-gestützte Untersuchung von Prospektionsfunden aus Wederath-Belginum (Kampagne 2004), BA thesis, Ludwig-Maximilians-University Munich, Germany, 41 pp., 2018.

Over, P. M.: Zur Dokumentation, Visualisierung und Analyse von Prospektionsfunden aus Wederath-Belginum, BA thesis, Ludwig-Maximilians-University Munich, Germany, 116 pp., 2018.

QGIS Development Team: QGIS Geographic Information System. Open Source Geospatial Foundation Project, available at: http: //qgis.osgeo.org, last access: 17 December 2018.

Silverman, B. W.: Density estimation for statistics and data analysis, Chapman and Hall, New York, USA, 1986.

Stiros, S. C.: Archaeological evidence of antiseismic constructions in antiquity, Annali di Geofisica, 38, 725-736, 1995.

Teegen, W.-R., Lukas, D., and Cordie, R.: Untersuchungen zur eisenzeitlichen Besiedlung von Wederath/Belginum, Archaeol. Mosellana, 9, 215-235, 2014 